\title{
Interfering Factors to the Abandonment of Smoking Cigarettes for the Participants of the National Program for Tobacco Control
}

Terezinha Alcântara Silva1, Maria Lúcia Ivo', Sandra Luzinete Félix de Freitas', Alexandra Maria Almeida Carvalho', Elenir Rose Jardim Cury Pontes ${ }^{1}$, Fernando de Freitas Monteiro', Janaína Ivo da Silva1, Ana Paula de Assis Sales', Márcia Rejane Freire de Oliveira², Rita de Cássia Lira da Silva ${ }^{3}$, Isabelle Campos de Azevedo ${ }^{3}$, Marcos Antonio Ferreira Júnior ${ }^{3}$

\section{Abstract}

Introduction: Smoking is considered a chronic and epidemic disease because the nicotine as well as with other drugs causes, physical, psychological and behavioral addiction.

Objective: To verify the interfering factors to the abandonment of smoking cigarettes participants of the National Program for Tobacco Control, assisted by Day-Hospital Professor Esterina Corsini of the Federal University of Mato Grosso do Sul, a central-west region of Brazil.

Method: Cross-sectional study conducted between August 2004 and December 2010, during the evaluation of smokers for admission to the National Program of Tobacco Control attended by Day-Hospital Professor Esterina Corsini of the Federal University of Mato Grosso do Sul. This is a national program coordinated by the Ministry of Health in Brazil. The study included 370 smokers older than 18 years old who sought the program spontaneously or were referred by health professionals, who agreed to participate. For data collection, a standardized form by the National Cancer Institute was used, administered by a psychologist in the initial interview. Data analysis was performed using the chi-square tests, chi-square trend, Fisher's exact and prevalence ratios with $95 \%$ confidence interval.

Results: Of the 370 smokers, $49.5 \%$ were male, and $50.5 \%$ were female, with a mean age of $47.47 \pm 11.52$ years old. As the education, $44.8 \%$ had at least nine years of study and $54.9 \%$ with up to eight
1 Federal University of Mato Grosso do Sul, Campo Grande/MS, Brazil.

2 Federal University of Recôncavo da Bahia, Cruz das Almas/BA, Brazil.

3 Federal University of Rio Grande do Norte, Natal/RN, Brazil.

\section{Contact information:}

Marcos Antonio Ferreira Júnior.

Address: Universidade Federal do Rio Grande do Norte, Centro de Ciências da Saúde, Departamento de Enfermagem. Avenida Salgado Filho, S/N, Lagoa Nova, Natal/RN, Brasil. CEP: 59078970.

$\equiv$ marcos_nurse@hotmail.com 
years of study. The age of onset of smoking was reported between 11 and 16 years old (57\%). The stomach problems were the most frequently cited comorbidity (52.2\%). Nicotine dependence measured by Fargeström test achieved Average, Low or Very Low score at $44.32 \%$, and High or Very High in $55.68 \%$ of the cases.

Conclusion: It was perceived that the greater the degree of nicotine dependence, the lower the number of smokers who successfully quit smoking.

\section{Keywords}

Nicotine; Smoking; Tobacco

Use Cessation; Therapeutics.

\section{Introduction}

Smoking is considered a chronic and epidemic disease, since nicotine as with the use of other drugs causes addiction, physical, psychological and behavioral $[1,2]$. It is estimated that five million deaths each year occur worldwide related to smoking, responsible for 10 thousand per day, which corresponds to the death of one person every six seconds, with a life expectancy derating in 15 years [3].

The person who has the habit of smoking developed tolerance, characterized by the amount of nicotine that the individual need to supply the brain receptors. The greater the tolerance, the greater the need for nicotine and physical addiction. Also, there are other factors that help maintain the addiction and smoking habits, such as cigarette industry marketing, sociocultural and behavioral factors [4].

A study conducted in Ribeirão Preto, in southeastern Brazil pointed out that frustrated smoking habit abandonment experiences were expressed by more than $80 \%$ of smokers. Thus, the people may need expert help due to their dependence. The subjects of that study also exhibited a high or very high degree of dependence on nicotine [5].

Many actions recommended by the World Health Organization through the Convention on Tobacco Control Picture (CTCP) have been implemented internationally to assist governments to combat this epidemic. Brazil is a signatory to the CTCP in 2003 and established the National Program for Tobacco Control (NPTC) that operates mainly in the following areas: prevention of the onset of smoking, especiaIly in children and adolescents; stimulus actions to smoking cessation; protection of non-smokers from exposure to smoke indoors; and implementation of laws to regulate the products arising from tobacco and marketing [6].

Through the National Cancer Institute (INCA), the Ministry of Health in Brazil coordinates the National Program for Tobacco Control (NPTC), which trains professionals to operationalize in the states and municipalities of the country [7]. In 2004, INCA technicians trained health professionals in the public area in the city of Campo Grande, the state capital of Mato Grosso do Sul (MS), a center-west region of Brazil, to coordinate smoking cessation groups in their municipalities.

In August of the same year, a multidisciplinary group of professionals from the areas of psychology, medicine, nursing, nutrition and physiotherapy started the implementation of the NPTC at DayHospital Professor Esterina Corsini of the Federal University of Mato Grosso do Sul (UFMS). On the same date, the first group of smokers selected for this study was formed, with participants referred by professionals of UFMS or spontaneous demand. From this date, the groups were systematically trained every two months. 
With the progress and structure of the program, it was necessary an evaluation of this initiative because, there were questions about different aspects over the years, such as a number of cases attended, epidemiological profile (clinical, socio-demographic and smoking history), the effectiveness of the approach used and the effective cessation of smoking.

Based on these aspects, the following research question was formulated: which factors interfere in the abandonment of smoking cigarettes in group participants attended in the National Program for Tobacco Control?

Thus, this study aims to determine the interference factors to the abandonment of smoking cigarettes participants of the National Program for Tobacco Control, attended in the Day-Hospital Professor Esterina Corsini of the Federal University of Mato Grosso do Sul, a central western region of Brazil.

\section{Method}

It is a cross-sectional study conducted between August 2004 and December 2010 during the evaluation of smokers for admission to the National Program for Tobacco Control attended by Day-Hospital Professor Esterina Corsini of the Federal University of Mato Grosso do Sul, Brazil.

The study population consisted of all participants attending the service with the intention to stop the habit of smoking tobacco and agreed to participate voluntarily in the study. According to the program, the former smoker is the participant who claimed to have been abstinent for 12 months. In this study, only those who reported the cessation of smoking when contacted were considered abstinent.

Patients evaluated by the psychology service during the admission interview in Group Cessation of Smoking from August 2004 to December 2010 were included. Indians, under 18, pregnant women and those who did not agree to participate and did not sign the Consent and Informed Form (TCLE) were excluded.
Data collection was performed after approval of the research protocol by the Research Ethics Committee, using a standard form and published by INCA. The form consists of variables for patient's identification (gender, age group and education), physical examination (weight, height, blood pressure, the he smoked the last cigarette, among others), past medical history (lesions in the mouth, diabetes mellitus, hypertension, heart diseases, malignant tumor, seizures, depression, psychological treatment), smoking history and evaluation of the degree of motivation. The degree of dependence was punctuated by the Fagerström Test for Nicotine Dependence (FTND), evaluating the following questions: How soon after waking up do you smoke your first cigarette? Do you find it difficult not to smoke in prohibited places, such as churches, buses, etc.? What cigarette during the day brings the most satisfaction? How many cigarettes do you smoke per day? Do you smoke more frequently in the morning? Do you smoke even sick?

For each answer, a certain value is assigned, and the sum of points allows the evaluation of the degree of dependence (very low: 0-2; low: 3-4, average: 5; high: 6-7; and high: 8-10), according to the NPTC Protocol of the Ministry of Health. The test was validated in Brazil by Carmo and Pueyo [8], and it was renamed as Nicotine Dependence Test (NDT).

Participants were questioned individually during the evaluation for admission to the cessation group, in a private atmosphere. At that time, the objectives of the NPTC and research were explained, and if they were in agreement with that, they signed the consent form.

Data were analyzed using descriptive statistics. To verify possible associations between the study variables, the Chi-square tests, chi-square trend, Fisher exact were used and calculated prevalence ratios with their respective $95 \%$ confidence intervals. To estimate the adjusted reasons prevalence, Cox Regression was used (time equal to one unit) using the significant variables greater than $20 \%$. 
Epi Info 3.5.1 software and BioEstat version 5 were used [9].

This study was approved by the Ethics Research Committee of the Federal University of Mato Grosso do Sul, under Protocol N 1,811, of September 30, 2010

\section{Results}

\section{Socio-demographic and cultural data}

Table 1 shows that of the 370 smokers who attended for the first interview, 187 (50.5\%) were men and 183 (49.5\%) were women, most of them

Table 1. Number and percentage of smokers by smoking cessation and identification of variables. Campo Grande/MS, 2006-2010 $(n=370)$.

\begin{tabular}{|c|c|c|c|c|c|c|}
\hline \multirow{3}{*}{$\begin{array}{c}\text { Domains/ } \\
\text { Facets }\end{array}$} & \multicolumn{4}{|c|}{ Smoking cessation } & \multirow{3}{*}{$\begin{array}{c}\mathrm{PR}^{\mathrm{a}} \\
(\mathrm{IC} 95 \%)\end{array}$} & \multirow{3}{*}{$p$} \\
\hline & \multicolumn{2}{|c|}{ Yes $(n=66)$} & \multicolumn{2}{|c|}{ No $(n=304)$} & & \\
\hline & No & $\%$ & No & $\%$ & & \\
\hline \multicolumn{7}{|l|}{ Gender } \\
\hline Female & 36 & 19.7 & 147 & 80.3 & 1 & \multirow{2}{*}{$0.362^{b}$} \\
\hline Male & 30 & 16.0 & 157 & 84.0 & $1.23(0.79-1.90)$ & \\
\hline \multicolumn{7}{|l|}{ Age } \\
\hline $\begin{array}{l}\text { Without } \\
\text { information }\end{array}$ & 2 & 6.5 & 29 & 93.5 & - & \multirow{4}{*}{$0.348^{c}$} \\
\hline$\geq 60$ & 9 & 22.0 & 32 & 78.0 & 1 & \\
\hline$\geq 40<60$ & 44 & 19.5 & 182 & 80.5 & $1.13(0.60-2.13)$ & \\
\hline$<40$ & 11 & 15.3 & 61 & 84.7 & $1.44(0.65-3.18)$ & \\
\hline \multicolumn{7}{|l|}{ Education } \\
\hline $\begin{array}{l}\text { Without } \\
\text { information }\end{array}$ & - & - & 1 & 100.0 & - & \multirow{5}{*}{0.996} \\
\hline $\begin{array}{l}\text { Illiteracy/ } \\
\text { Literacy }\end{array}$ & 27 & 18.5 & 119 & 81.5 & 1 & \\
\hline Elementary & 16 & 15.7 & 86 & 84.3 & $1.18(0.67-2.07)$ & \\
\hline High school & 21 & 19.6 & 86 & 80.4 & $0.94(0.56-1.57)$ & \\
\hline Higher level & 2 & 14.3 & 12 & 85.7 & $1.29(0.34-4.88)$ & \\
\hline
\end{tabular}

Note: if $p \leq 0.05$ statistically significant difference. The "without information" was removed from the calculation test. a: PR = Prevalence Ratio; b: Chi-square test; c: Chi-Square trend test.

(61.1\%) were aged between 40 and 59 years old and the average age was $47.47 \pm 11.52$. As for education, $67 \%$ of the sample reported having studied up to elementary school. When related to smoking cessation, these identification variables showed no significant association.

\section{Smoking history, degree of nicotine dependence and smoking cessation}

Concerning the smoking history, it was observed that $11.6 \%$ of participants reported the habit starting between five and ten years old, 57\% between 11 and 16 years old and $23.5 \%$ between 17 and 20 years old. Also, 34\% reported living with smokers at home. The degree of nicotine dependence as measured by the Fagerström scale scores were very high (21.9\%) high (33\%) and Average (19.5\%) (Table 2).

Table 2. Distribution of smokers by age at onset of smoking, living with smokers at home and nicotine addiction. Campo Grande/MS, 2006-2010 ( $n=370)$..

\begin{tabular}{|l|c|c|}
\hline \multicolumn{1}{|c|}{ Variables } & No & $\%$ \\
\hline Age of onset of smoking & & \\
\hline Without information & 2 & 0.5 \\
\hline 5 and 6 years old & 3 & 0.8 \\
\hline 7 and 8 years old & 15 & 4.1 \\
\hline 9 and 10 years old & 25 & 6.7 \\
\hline 11 and 12 years old & 56 & 15.1 \\
\hline 13 and 14 years old & 62 & 16.8 \\
\hline 15 and 16 years old & 93 & 25.1 \\
\hline 17 and 18 years old & 59 & 15.9 \\
\hline 19 and 20 years old & 28 & 7.6 \\
\hline 21 and 22 years old & 10 & 2.7 \\
\hline 23 and 24 years old & 3 & 0.8 \\
\hline 25 and 26 years old & 5 & 1.4 \\
\hline 27 to 34 years old & 4 & 1.1 \\
\hline 35 to 39 years old & 4 & 1.1 \\
\hline 40 to 59 years old & - & - \\
\hline 60 years old & 1 & 0.3 \\
\hline
\end{tabular}




\begin{tabular}{|l|c|c|}
\multicolumn{1}{c|}{ Variables } & No & $\%$ \\
\hline Smokers at home & & \\
\hline Without information & 1 & 0.3 \\
\hline No & 243 & 65.7 \\
Yes & 126 & 34.0 \\
\hline Nicotine dependence (Fagerström) & & \\
\hline Without information & 1 & 3.0 \\
\hline Very high & 81 & 21.9 \\
\hline High & 124 & 33.5 \\
Average & 73 & 19.7 \\
Low & 59 & 16.0 \\
\hline Very low & 32 & 8.6 \\
\hline
\end{tabular}

Table 3. Number and percentage of smokers according to the reasons to quit smoking and smoking cessation. Campo Grande/MS, 2004-2010 ( $n=370)$.

\begin{tabular}{|c|c|c|}
\hline Variables & No & $\%$ \\
\hline \multicolumn{3}{|l|}{ Reason to quit smokinga } \\
\hline Because it is affecting the health & 288 & 77.8 \\
\hline By fearing a future health problem & 286 & 77.3 \\
\hline For the welfare of the family & 117 & 31.6 \\
\hline Asked by the children & 113 & 30.5 \\
\hline By being antisocial & 105 & 28.4 \\
\hline Pressure from others & 96 & 25.9 \\
\hline Because he does not like to be dependent & 91 & 24.6 \\
\hline Being a bad example for children & 86 & 23.2 \\
\hline $\begin{array}{l}\text { Because he spends a lot of money with } \\
\text { the addiction }\end{array}$ & 60 & 16.2 \\
\hline By smoking restrictions in environments & 42 & 11.4 \\
\hline By causing halitosis & 1 & 0.3 \\
\hline \multicolumn{3}{|l|}{ Stopped smoking } \\
\hline Yes & 66 & 17.8 \\
\hline No & 304 & 82.2 \\
\hline
\end{tabular}

Smokers seeking the National Program for Tobacco Control at Day-Hospital Professor Esterina Corsini, reported several reasons for quitting smoking, highlighting the fact of smoking affecting their health $(77.8 \%)$ and fear of future health problems (77.3\%). However, the data in Table 3 show that after five years of implementation of the NPTC, only $17.8 \%$ of the 370 participants remained abstinent of cigarette.

The study participants reported various health problems and the most frequently were gastric disorders (52\%), depression (28.9\%), hypertension (21.4\%) and diabetes (8.4\%).

Table 4 shows the significant association ( $p=0.003$ ) between nicotine dependence measured by the Fagerström scale and the number of smokers who do not quit smoking.

Table 4. Number and percentage of smokers according to smoking cessation, the degree of nicotine dependence, living with smokers at home, participation in support groups and resource use to stop smoking. Campo Grande/MS, 2006-2010 (N=370).

\begin{tabular}{|c|c|c|c|c|c|c|}
\hline \multirow{3}{*}{ Variables } & \multicolumn{4}{|c|}{ Smoking cessation } & \multirow{3}{*}{$\begin{array}{c}\text { PR }^{\mathrm{a}} \\
(\text { IC 95\%) }\end{array}$} & \multirow{3}{*}{$\mathrm{p}$} \\
\hline & \multicolumn{2}{|c|}{ Yes $(n=66)$} & \multicolumn{2}{|c|}{ No $(n=304)$} & & \\
\hline & No & $\%$ & No & $\%$ & & \\
\hline \multicolumn{7}{|c|}{ Nicotine dependence } \\
\hline $\begin{array}{l}\text { Without } \\
\text { information }\end{array}$ & 1 & 100.0 & - & - & - & \multirow{6}{*}{$0.003^{c}$} \\
\hline Very low & 9 & 28.1 & 23 & 71.9 & 1 & \\
\hline Low & 15 & 25.4 & 44 & 74.6 & $1.11(0.55-2.24)$ & \\
\hline Average & 16 & 21.9 & 57 & 78.1 & $1.28(0.64-2.59)$ & \\
\hline High & 15 & 12.1 & 109 & 87.9 & $2.33(1.12-4.82)$ & \\
\hline Very high & 10 & 12.3 & 71 & 87.7 & $2.28(1.02-5.08)$ & \\
\hline \multicolumn{7}{|c|}{ Smokers at home } \\
\hline $\begin{array}{l}\text { Without } \\
\text { information }\end{array}$ & - & - & 1 & 100.0 & - & \multirow{3}{*}{$0.467^{b}$} \\
\hline No & 46 & 18.9 & 197 & 81.1 & 1 & \\
\hline Yes & 20 & 15.9 & 106 & 84.1 & $1.19(0.74-1.93)$ & \\
\hline
\end{tabular}




\begin{tabular}{c|c|c|c|c|c|c}
\multirow{4}{*}{ Variables } & \multicolumn{3}{|c|}{ Smoking cessation } & & \\
\cline { 2 - 3 } & Yes $(n=66)$ & No $(n=304)$ & $\begin{array}{c}\text { PR }^{a} \\
(I C ~ 95 \%)\end{array}$ & p \\
\cline { 2 - 3 } & No & $\%$ & No & $\%$ & &
\end{tabular}

Participation in support groups

\begin{tabular}{|l|c|c|c|c|c|c|}
\hline Yes & 6 & 23.1 & 20 & 76.9 & 1 & $0.433^{d}$ \\
\hline No & 60 & 17.4 & 284 & 82.6 & $1.32(0.63-2.77)$ & \\
\hline
\end{tabular}

Use of resources to stop smoking

Without information

1100.0

Yes

\begin{tabular}{l|l|l|l}
15 & 12.8 & 102 & 87.2
\end{tabular}

1

$0.084^{b}$

No

$5120.220179 .8 \quad 0.63(0.37-1.08)$

Note: if $p \leq 0.05$ statistically significant difference. The "without information" was removed from the calculation test.

a: PR = Prevalence Ratio; ${ }^{b}$ : Chi-square test; ${ }^{c}$ : Chi-Square trend test.

Table 5 shows the association between nicotine dependence and smoking cessation in the multivariate analysis.

Table 5. Multivariate analysis for smoking cessation according to the variables included in the model. Campo Grande/MS, 2006-2010 $(n=370)$.

\begin{tabular}{|l|c|c|c|}
\multicolumn{1}{|c|}{ Variables } & $\mathbf{p}$ & $\begin{array}{c}\text { Prevalence } \\
\text { ratio (PR) }\end{array}$ & Cl 95\% (PR) \\
\hline Nicotine dependence & 0.037 & 1.22 & $1.01-1.48$ \\
\hline Body Mass Index & 0.108 & 0.79 & $0.60-1.05$ \\
\hline $\begin{array}{l}\text { Resources to stop } \\
\text { smoking }\end{array}$ & 0.128 & 0.64 & $0.36-1.14$ \\
\hline $\begin{array}{l}\text { Diabetes } \\
\text { Convulsive crisis }\end{array}$ & 0.148 & 0.23 & $0.03-1.69$ \\
\hline Malignant tumor & 0.201 & 1.99 & $0.69-5.68$ \\
\hline Hypertension & 0.437 & 0.75 & $0.04-1.99$ \\
\hline
\end{tabular}

Note: Cox regression - if $p \leq 0,05$, statistically significant difference.

\section{Discussion}

This study found a significant association between the Fagerström Test and the variable dependence on nicotine, indicating that the greater the degree of dependence on nicotine, the lower the number of smokers who quit. Other studies have also reported that nicotine addiction hinders are smoking cessation $[5,10,11]$.

The results of this study are similar to those of a survey conducted in Chile, which found that $45 \%$ of smokers in school age began the habit between 12 and 13 years old, with a gradual increase in the daily consumption of cigarettes as advancing in high school [12]. Research developed by the Global Youth Tobacco Survey (GYTS) showed that the prevalence of tobacco used in the age group of 13 to 15 years old was $35.1 \%$ in Chile and $2.8 \%$ in Canada. [13] Another study conducted in Londrina, the state of Paraná, southern Brazil, showed that the factors age $\geq 15$ years old and have smoking friends were associated in a multivariate analysis to the regular use of cigarettes. [14]

The ease of access to cigarettes and the idea that smoking is a sign of maturity and freedom were other marked points [15]. This age group is easily influenced by smoking industry marketing investing millions to reach this population [16].

According to INCA, during a lawsuit by US states against the tobacco industry, there were secret files that were part of internal documents of large Tobacco companies. In these documents, the children and young people were called "restocking reserves" and seen as strategic targets because they must become dependent on cigarettes still early to replace those who quit an addiction or died. INCA reported on its website some internal memos clippings of the tobacco industry, including some dealing with the marketing to children and adolescents, as circulated in the media on January 23, 1975, which stated that "They represent the cigarette business tomorrow. As the age group of 14 to 24 years old matures, they become the key part of the total volume of cigarettes, at least for the next 25 years" [17].

Among those surveyed in this study and those who sought the program for the cessation of smoking, 49.5\% were female. A female audience is a group in which the prevalence of smoking has 
grown, with a range in 2010 of 250 million smokers worldwide, highlighting the investment of smoking industry in achieving their goal [18].

The results of a global survey by the Global Youth Tobacco Survey (GYTS), WHO initiative since 1998, showed a feminization increasing of smoking. However, the prevalence among young women in some countries is equal or greater than that men [19].

Cigarette industries use a fully focused strategy to reach this audience, supported by research that evaluates the behavior and reactions of women to the stimuli, such as the color of cigarette packs, trying to reach the female imagination with their meaning, as blue symbolizing peace, pink meaning femininity and red meaning power. Besides these, other strategies are used, such as the creation of aloes and flavored cigarettes and the association of smoking with the idea of autonomy, strength, refinement, contemporaneity [20].

By analyzing on the precocity at the beginning of smoking cigarettes, it is worth remembering that the sooner the onset of smoking, the bigger the likelihood of being affected by diseases such as respiratory, cardiocirculatory and neoplastic, besides the risk of death by smoking [18]. Smokers who seek treatment are motivated by concern for the health, the risk of illness as a result of this habit and the manifestation of the effects of smoking over the years [5, 21].

Regarding the abandonment of the habit of smoking tobacco, 66 of the participants reported remaining abstinent. Another study conducted with employees of a hospital in the South of Brazil reported that $36 \%$ of smokers in the sample had relapsed. Although they had made several attempts to quit smoking [22].

About the cessation of smoking and level of education, it was observed that there was no significant association. In research conducted by the surveillance system and Risk and Protective Factors for Chronic Diseases Survey Telephone (VIGITEL) in Brazilian state capitals and the Federal District in 2006, 2007, 2008 and 2009 to individuals 18 years and over, it was found the number of years of education influenced the smoking cessation [23]. A prospective cohort study conducted with smokers in the United States, Canada, UK and Australia also showed an association between education and the abrupt abandonment of the habit of smoking tobacco [24].

As can be seen in this study, quitting tobacco smoking habit is a difficult challenge, given that out of ten smokers for this purpose, only three did it without help. This study had some limitations, such as difficulties in contacting some of the participants attended, by the change of address or change of phone number without an appropriate update in the database. However, these losses did not interfere with our results.

\section{Conclusion}

It was possible to verify the interfering factors in the abandonment of smoking cigarettes participants of the National Program for Tobacco Control in the Day-Hospital Professor Esterina Corsini of the UFMS with this study. From the analyzed results, mainly it can be inferred that the greater the degree of nicotine dependence, the lower the number of smokers who successfully quit smoking.

These results show the relevance of the thematic discussion to alert health professionals about the responsibility towards children and adolescents in the implementation of policies for the prevention of smoking to combat this epidemic and to develop actions to promote within the NPTC in units that offer treatment for smoking effectiveness.

It is recommended to continue the NPTC because it is a privileged space for reception of smokers seeking help for the cessation of smoking. It is suggested that in the initial assessment of the smoker, there is a separation level of nicotine dependence in groups, to stronger work motivation for smoking cessation, opening groups in the evening hours to 
allow accessibility prevented to workers from attending at other times and conduct active searches to monitor the membership of the participant to the program systematically.

\section{References}

1. Rosemberg, J. Pandemia do tabagismo: enfoques históricos e atuais. São Paulo: Secretaria Estadual de Saúde; 2002. Available from: http://bases.bireme.br/cgi-bin/wxislind.exe/iah/ online/?IsisScript=iah/iah.xis\&src=google\&base=LILACS\&lang= p\&nextAction $=$ Ink\&exprSearch=332824\&indexSearch $=I D$

2. Muakad, IB. Smoking: major avoidable cause worldwide. R. Fac. Dir. Univ. São Paulo. 2014; 109: 527-58. Available from: http:// www.revistas.usp.br/rfdusp/article/view/89244

3. World Health Organization. The global tobacco crisis: tobacco - global agent of death. Who report on the global tobacco epidemic, 2008: the MPOWER package. Geneva: WHO; 2008. Available from: http://www.who.int/tobacco/mpower/mpower report tobacco crisis 2008.pdf.

4. Ismael SMC. Efetividade da terapia cognitivo-comportamental na terapêutica do tabagismo. São Paulo. Tese [Doutorado] Faculdade de Medicina da USP; 2007. Available from: http:// www.teses.usp.br/teses/disponiveis/5/5160/tde-21062007113413/publico/SilviaMCurylsmael.pdf

5. Karen SKK, Oliveira ML, Pádua Al, Vieira F, Martinez JAB. Clinical characteristics of smokers seen in a smoking cessationreference center. Medicina Ribeirão Preto (Online) 2012 set; 45(3): 33742. Available from: http://www.revistas.usp.br/rmrp/article/ view/47674/51413

6. Cavalcante TM. Tobacco Control in Brazil: Advances and Challenges. Rev. Psiq. Clín. 2005; 32(5): 283-300. Available from: http://www.scielo.br/pdf/rpc/v32n5/27703.pdf

7. Rossaneis MA, Machado RCBR. Tobacco cessation on patients assisted in an ambulatory of tobacco dependence treatment. Cienc. Cuid. Saúde. 2011; 10(2): 306-13.

8. Carmo JT, Pueyo AA. A adaptação do português do Fagerström Test for Nicotine Dependence (FTND) para avaliar a dependência e tolerância à nicotina em fumantes brasileiros. Rev Bras Med. 2002; 59(1/2): 73-80. Available from: http://www.moreirajr. com.br/revistas.asp?id materia=1798\&fase=imprime

9. Ayres M, Ayres Jr M, Ayres DL, Santos AAS. BioEstat. Aplicações estatísticas das Ciências Bio-médicas. Versão 5.0. 2007. Belém, Pará: Sociedade Mamirauá; xvii+359p.

10. Meier DAP, Vannuchi MTO, Secco IAO. Withdrawal of treatment for smoking in a Program of a Municipality of Northern Paraná. Espaç. Saúde (Online). 2011; 13(1): 25-44. Available from: http:// www.uel.br/revistas/uel/index.php/espacoparasaude/article/ view/10020/9349
11. Barreto RB, Pincelli MP, Steinwandter $R$, Silva $A P$, Manes J, Steidle LJM. Smoking among patients hospitalized at a university hospital in the south of Brazil: prevalence, degree of nicotine dependence, and motivational stage of change. J. bras. pneumol. 2012; 38(1): 72-80. Available from: http://www. scielo.br/pdf/jbpneu/v38n1/v38n1a11.pdf

12. Amarales, L. El tabaquismo, una patología pediátrica. Neumol. Pediátr. 2010; 6(1):22-28.

13. OPAS- Organización Panamericana de la Salud. Informe sobre Control del Tabaco para la Región de las Américas. Washington, DC, 2013. p. 1. Disponível em: http://www.paho.org/hq/index. php?option=com docman\&task=doc view\&gid=23415\&ltemid

14. Menezes AHR, Dalmas JC, Scarinci IC, Maciel SM, Cardelli AAM. Factors associated with regular cigarette smoking by adolescents from public schools in Londrina, Paraná, Brazil. Cad. Saúde Pública. 2014; 30(4): 774-784. Available from: http:// www.scielo.br/pdf/csp/v30n4/0102-311X-csp-30-4-0774.pdf

15. Fonseca AC, Simões MCT. Os malefícios do tabaco na infância e na adolescência. Rev. Port. Pedag. 2010; 44(1): 217-36. Available from: http://iduc.uc.pt/index.php/rppedagogia/article/ view/1277/725

16. Kuhnen M, Boing AF, Oliveira MC, Longo GZ, Njaine K. Smoking and associated factors in Brazilian adults: a population-based study. Rev. bras. epidemiol. 2009; 12(4): 615-626. Available from: http://www.scielosp.org/pdf/rbepid/v12n4/11.pdf

17. Instituto Nacional do Câncer José Alencar Gomes da Silva. Saiba mais sobre os arquivos secretos da indústria do tabaco. Available from: http://www1.inca.gov.br/tabagismo/frameset. asp?item=atento\&link=arquivos secretos.pdf

18. World Health Organization. Tobacco Free Initiative: Gender and tobacco with an emphasis on marketing to women. Geneva: WHO; 2010. Available from: http://www.who.int/tobacco/ wntd/2010/announcement/en/index.html

19. World Health Organization. Gender, Woman and Tobacco Epidemic. Edited by Jonathan M. Samet and Soon-Young Yoon. Manila 2010. Available from: http://whqlibdoc.who.int/ publications/2010/9789241599511_eng.pdf?ua=1

20. Lombardi EMS, Prado GF, Santos U de P, Fernandes FLA. Women and smoking: Risks, impacts, and challenges. J. bras. pneumol. 2011; 37(1): 118-28, 2011. Available from: http://www.scielo.br/ pdf/jbpneu/v37n1/en v37n1a17.pdf

21. Russo AC, Azevedo RCS. Factors that motivate smokers to seek outpatient smoking cessation treatment at a university general hospital. J Bras Pneumol. 2010; 36(5): 603-11. Available from: http://www.scielo.br/pdf/jbpneu/v36n5/en_v36n5a12.pdf 
22. Echer, IC, Corrêa APA, Lucena AF, Ferreira SAL, Knorst MM. Prevalence of Smoking Among Employees of a University Hospital. Rev. Latino-Am. Enfermagem, Ribeirão Preto. 2011; 19(1): 179-86. Available from: http://www.scielo.br/pdf/rlae/ v19n1/24.pdf

23. Silva, GAE, Valente JG, Malta DC. Trends in smoking among the adult population in Brazilian capitals: a data analysis of telephone surveys from 2006 to 2009. Rev. bras. epidemiol. 2011; 14(supl.1): 103-114. Available from: http://www.scielo.br/ $\mathrm{pdf} / \mathrm{rbepid} / \mathrm{v} 14 \mathrm{~s} 1 / \mathrm{en}$ a11v14s1.pdf

24. Siahpush M, Yong HH, Borland R, Reid JL. Socioeconomic position and abrupt versus gradual method of quitting smoking: findings from the International Tobacco Control Four-Country Survey. Nicotine Tob Res. 2010; 12(Suppl 1): 58-63. Available from: http://ntr.oxfordjournals.org/content/12/suppl 1/S58

Vol. 9 No. 175 doi: $10.3823 / 2046$
Publish in International Archives of Medicine

International Archives of Medicine is an open access journal publishing articles encompassing all aspects of medical science and clinical practice. IAM is considered a megajournal with independent sections on all areas of medicine. IAM is a really international journal with authors and board members from all around the world. The journal is widely indexed and classified Q1 in category Medicine. 